\title{
Sustainability, Innovative Orientation and Export Performance of Manufacturing SMEs: An Empirical Analysis of the Mediating Role of Corporate Image
}

\author{
Francisco Villena-Manzanares, Jaime Eduardo Souto-Pérez \\ European University, University of Seville (Spain) \\ fvillena@us.es,jaime.souto@uam.es
}

Received: May 2015

Accepted: January 2016

\section{Abstract:}

Purpose: The objective of this research is to empirically analyze the role played by corporate image, sustainability, and innovative orientation on export performance.

Design/methodology/approach: hypothesis testing was conducted with a sample of 180 manufacturing SMEs in Seville (Spain) and a structural equation system is modeled using the technique Partial Least Squares (PLS). The research model includes the following variables: corporate image, sustainability, and innovative orientation on export performance.

Findings: The results show the positive effect of sustainability and innovative orientation on export performance, as well as the mediator effect of corporate image on these relationships.

Research limitations/implications: The results may be more general if we had used a national sample and cross cultural. The conclusions cannot be directly extrapolated to other countries. This work propose future research doing the same study with other types companies.

Originality/value: Corporate image requires special attention, as it acts as a filter of the impacts of sustainability and innovative orientation. The creation of corporate image not only as a result of tangible items, but as a result of the actions and behavior of the company. In this research is showed that there is a high level of complexity in the management of intangibles 
since the intangibles influence each other, such as the influence of sustainability and innovative orientation on corporate image. Managers should focus on proper design and management of the company image, in order to compete and grow in the international area.

Keywords: corporate image, sustainability, innovative orientation, exports performance

\section{Introduction}

Any organization offers the public an image of the company which is crucial from a strategic point of view. However, at present, there is no literature yet available analyzing how the corporative image generated by the company influences business growth (Tran, Nguyen, Melewar \& Bodoh, 2015).

As is known, industrial companies compete in the domestic market and tend to use the export strategy to compete and position their products in international trade. The literature asserts that the export is a revelation of business success and is also a strategy to increase profitability. The arguments in this study are supported by Theory on Resources and Capabilities (Barney, 1991; Penrose, 1959) and the Theory of Dynamic Capabilities (Hamel \& Prahalad, 1990; Teece \& Pisano, 1994; Teece, Pisano \& Shuen, 1997; Teece, 2007). The Theory based on Resources and Capabilities explains the importance of intangible assets for the competitive success of the company. The theoretical approach of Dynamic Capabilities explains that internal capabilities are responsible for responding to changes in the environment (Zajac, Kraatz \& Bresser, 2000); and that of innovation for generating the ability to develop new solutions (Teece \& Pisano, 1994). Measuring and quantifying the business intangible resources, is a complex task, since this comes from information and conceived knowledge within the company (as organizational culture).

The objective of this research is to empirically analyze the role played by corporate image, sustainability, and innovative orientation on export performance.

However, in this research, sustainability and innovative orientation of the company with the corporate image are business intangibles that we study empirically in relation to export performance. The relationship between innovation and internationalization of companies, such as export performance having earned a place of interest among researchers, has been extensively researched. However, the approach of the relationships as presented in this research does not exist in the literature, although there are studies which have considered similar variables (Rhee, Park \& Lee, 2010; Fonseca \& Lima, 2015). The originality of this research on manufacturing SMEs is due to the added value it can provide the results to these businesses, whether exporting or considering using export strategy. 
The present study is divided into several sections; the first is the introduction; the second the literature background, in which the variables used are defined, the research hypotheses and the research model is presented; in the third section the methodology used to test the hypotheses is presented through a sample of industrial SMEs; the fourth details the results achieved through structural equation modeling; and the final section gives the main conclusions and practical implications of this study.

\section{Literature Background, Conceptual Model, and Hypotheses}

\subsection{Sustainability as Organizational Culture}

A global definition for the concept of sustainability, which in principle is concerned with meeting "the needs of the present without compromising the ability of future generations to meet their own needs" (World Commission on Environment and Development, 1987: page 43). In accordance with Fonseca (2012), most definitions take into consideration, the economic, social and environmental dimensions. Moreover, the term "green" is often interchanged with "sustainable" (Chien \& Shih, 2007). In short, sustainability calls for production enterprises to make a commitment to the future and assume comprehensive responsibility for the footprint they leave behind (Seuring, 2004). On the other hand Green production is the application of environmentally and socially sensitive practices to reduce the negative impact of manufacturing activities.

ISO (International Standardization Organization) is the entity responsible for promoting international standards of manufacturing, trade and communication worldwide. Quality Management is related to ISO 9000 family and environmental management is related to ISO 14000 family. Quality Management and environmental management are business practices that may benefit companies.

Quality certification in manufacturing SMEs' scope shows the degree to which enterprises are committed with quality, and this fact has an effect on increasing clients' confidence in acquiring final products with a higher acceptance in the markets. Accordingly, it can be affirmed that quality certification according to ISO standards contributes to a better control of the productive process, and this contributes to a higher competitiveness.

In accordance with Fonseca (2015), "ISO 14001 is an International Standard of worldwide acceptance based on the concept that better environmental performance can be achieved when environmental aspects are systematically identified and managed giving a major contribution to Sustainability, through pollution prevention, improved environmental performance and complying with applicable laws". 
For example, benefits of the ISO 9001 standard are: Exports growth, sales growth, profitability, improvement in competitive position/competitive advantage, Improvement in systematization, Efficiency (Improved quality in product/service), Improved image, among others (Tarí, Molina-Azorín \& Heras, 2012). For example, benefits of the ISO 14001 standard are: improved image, improvement in customer satisfaction, improved staff results, improved competitive edge and improved relations with stakeholders, improved sales, improved product quality and increased market share, among others (Tarí et al., 2012).

At present, some studies have shown the importance of commitment to sustainable development for the benefit of companies through different aspects. For example, the company can be more competitive producing the same product with fewer resources or the company can manufacture innovative products for which the market is willing to pay a higher price (Marcus \& Fremeth, 2009; Shrivastava, 1995), improving its international competitiveness (Porter \& Van Der Linde, 1995).

A suitable sustainable behavior is related to new market opportunities. These strategies are common to maintain the survival of the company. However, consideration for the environment within the strategy of the company is a complex issue and a cause for concern due to, for example, new regulations on environmental issues (Lewis \& Harvey, 2001). Any manufacturing firm with a production process in its facilities generates waste which is pollutant so must uphold commitments to society and the environment. Therefore, some companies have started to establish an environmental management system to reduce environmental pollution. Some have even acquired ISO certifications, which is demonstrable proof of good waste management for customers.

There are numerous studies that have incorporated environmental care within the organization as a critical factor to develop sustainable behavior. However, none of these approaches refer to the value generated in the business as a result of the manager implementing sustainable behavior in the organization, when the company exports its products. The position adopted by the manager regarding implementing a sustainable culture depends primarily on their personal characteristics (Cordano \& Frieze, 2000; Flannery \& May, 2000; Ramus \& Steger, 2000), and secondly their assessment of the environmental issues as either opportunities or threats for the company (Sharma, 2000). Entrepreneurial behaviors that are oriented towards a sustainable culture, implementing an environmental management system, recycling leftover materials, and manufacturing with recycled or organic products, among others, are all possible factors to be considered. Currently it is more common to label end products "green product" for end customers to identify the manufacturer as sustainable and environmentally friendly, thereby enhancing its reputation. 


\subsection{Innovative Orientation as a Source of Competitive Advantages}

In the literature, we find that the concept of innovation and its components have adopted different forms due to the diversity of contributions over the past decades. For this reason, this research uses innovative orientation to refer to those internal powers of the organization that make reference to business innovation. Innovation, as it is seen today, it can be associated with manufacturing companies. Innovation is defined as the process of introducing new combinations of factors of production to create a better, newer, or different product that impacts positively on the market, generating economic and social benefits (Martínez, 1991: page 237).

Other researchers refer to innovation as a way for employers to see new business opportunities (Drucker, 1986). Whilst reviewing the literature, the term innovation management was found, whereby it is assumed that successful entrepreneurs are constantly innovating and innovation is positioned at the forefront of business concerns (Peters \& Austin, 1989). The literature currently available shows a generation of new ideas, new ways of thinking in business, new ways of entering the market, solving problems, maintaining leadership in the market, having the ability to produce with commercial viability, the ability to find market opportunities in problems, using new knowledge to manufacture a product, are all contributions that allude to the conceptual dimension of business innovation (Kanter 1987; Adair, 1992; Drucker, 2000; Freeman, 1982; Valdés, 2002).

Innovation can be materialized in the design of a new product, a new process of production, a new marketing approach or a new way of organizing. Innovation can hence include any activity generated in the operation of the company (Porter, 1991). In the above order of ideas, we can affirm that innovative orientation allows the company to have a competitive advantage and is a fundamental variable that must be studied when a company wishes to become successful within foreign markets.

Studies which have analyzed innovation in manufacturing SMEs, highlighting that innovation in these businesses is a process that is based primarily on the basis of their internal knowledge (Freel \& Harrison, 2006; Gebauer, Woon-Nam \& Parsche, 2005; Kaufman \& Tödtling, 2002).

\subsection{Determinants of Export Success}

For some companies export means growth but for others it is a way of staying in the market, mainly due to high international competition. This paper conceives export as the transfer of products from one country to another, in accordance with Welch and Luostarinen (1988), who conceived internationalization as the process of increasing operations trade of products between countries. 
The literature on internationalization of a company determines that the most practical way of becoming incorporated into foreign markets is through export. Due to the above, extensive research has been conducted to identify the main factors that explain the export performance of firms. The literature available asserts that export is a manifestation of business success and is also a strategy to increase profitability. Many researchers have tried to provide answers with regards to the factors contributing to the export success of SMEs (Leonidou, Katsikeas \& Piercy, 1998; Madsen, 1987; Miesembock, 1988, Zou \& Stan, 1998), the main factors influencing export performance (Bilkey, 1978; Miesembock, 1988; Aaby \& Slater, 1989; Gemunden, 1991, Chetty \& Hamilton, 1993; Leonidou, Katsikeas \& Piercy, 1998), or the factors that determine the success of the export result (Aaby \& Slater, 1989; Leonidou, Katsikeas \& Piercy 1998; Chetty \& Hamilton, 1993; Zou \& Stan, 1998; Leonidou, Katsikeas \& Samiee, 2002).

Regarding export performance, the literature shows a wide range of theories and models that have tried to provide explanations for certain internal and external aspects of the company that have an impact on the ability of the entrepreneur to export, sometimes showing contradictory results with some variables. It is undeniable that in this workspace we play with variables of psychological character that depend on the manager. According to Acedo \& Galan (2011), the psychological characteristics of managers have an influence on the international behavior of SMEs.

At present, there is no agreement in the academic literature concerning business components which directly affect the export result (Villena-Manzanares \& Souto-Pérez, 2015; Sousa, Lengler, \& Martínez-López, 2014; Navarro-García, Schmidt \& Rey-Moreno 2015; Acedo \& Galán, 2011; Shoham, 1998; Zou, Taylor \& Osland, 1998). However, it is clear from the literature that internal aspects of a company have taken greater relevance over external aspects to explain the determinants of export performance. (Zou \& Stan, 1998). Moreover, this paper is based on the theoretical vision of a company based on its resources and capabilities, where only the internal elements of the company are the real actors on differences in firm performance (Wernerfelt \& Mongomery, 1988; Hansen \& Wernerfelt, 1989; Rumelt, 1991). In accordance with this, we have provided a model that tries to clarify the impact of certain intangible resources common in industrial SMEs with their export performance.

\subsection{The Corporate Image as a Principle of Business Management}

In such a competitive world, it is crucial for management to be concerned with the perception different audiences have on their organizations from a global perspective. The concept of corporate image has been treated differently by different authors, such as Bernstein (1986), Capriotti (1999) or Villafañe (1999) among others. There is no current agreement on its definition due to the conflict that surrounds its concept. This paper will hence address the corporate image of the company as, according to Dowling (1994), the print which generates an organization (beliefs \& 
feelings) in the mind of the public. The image is generated by the accumulation of impressions of the company. Strategic action is hence necessary to influence such perceptions, which can only be generated within the Organization (Zinkhan, Jaishankar, Anupam \& Linda, 2001).

In this research, corporate communication is generated from within the company, the corporate image is designed by the company, its identity is associated with a distinctive corporate (fundamental features that differentiate organizations), and the corporate reputation as the judgement made about the organization, from the public's point of view. Various theoretical models have emerged which highlight the need to first define the corporate identity, followed by a program to communicate this. The identity is understood as the reality of the corporation (Van Rekom, 1993; Balmer, 1995), what the company is (Cappriotti, 1999), or the perception that senior management has of it (Bromley, 2000). All companies, regardless of the sectors they operate in produce a certain image of business before the public, due to the aesthetics of their facilities, philosophy, culture and organization logos, product image, color, and so on. From a strategic point of view corporate image is generated within the company, and is transmitted to the outside.

In the literature there is a certain consensus that a company must generate an image consistent and representative of its activity, to distinguish itself from the competition, so the image allows for differentiation in the markets (Capriotti, 1999). Corporate image is an intangible that managers must recognize as a strategic asset for the organization (Villafañe, 1993).

The creation of a strategic corporate image is a process for which the internal management of the company is responsible (Dowling, 1994). In this sense, internal management plays a key role in corporate development, which consists in spreading the mission and values of the organization and implementing a coherent vision of business (Simoes, Dibb \& Fisk, 2005). It is important to manage the aesthetic (shapes, colors) along with audio communication in an organization, in order to express its culture and values (Schmitt, Simonson \& Marcus, 1995). Once the members of the organization define its mission and values, these are communicated to both internal and external stakeholders (Gioia, Schultz \& Corley, 2000). The corporate image is not only another intangible, but rather provides an element of differentiation in increasingly saturated markets, which is something management must recognize and use to their advantage but internally and strategically.

The research model is presented in Figure 1. 


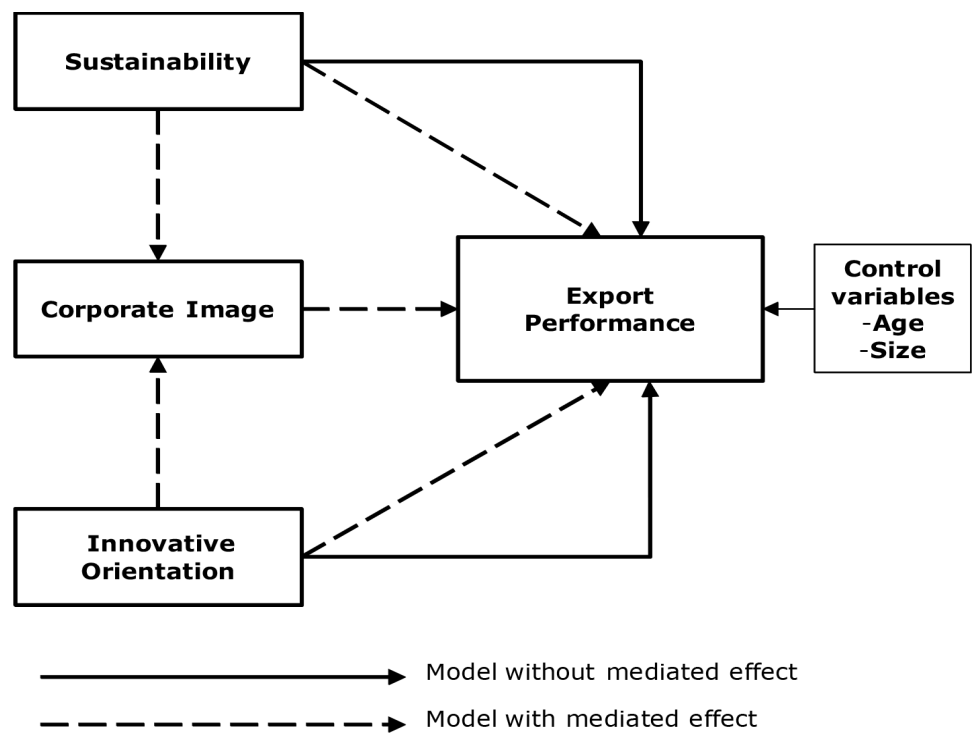

Figure 1. Research Model

In response to the above, the following hypotheses have been formulated:

H1: Sustainability has a positive direct effect on export performance.

H2: Innovative orientation has a positive direct effect on export performance.

H3: The corporate image acts as a mediator variable between sustainability and export performance.

H4: The corporate image acts as a mediator variable between innovative orientation and export performance.

\section{Methodology and Research Design}

\subsection{Sample, Data Collection and Procedure}

A random sample of 180 manufacturers in Seville (Spain) was used (this represents 7.5\% of total population). The sample contained both exporters and non-exporters and was obtained by consulting databases from industrial estates. Initial contact by telephone was conducted, and all companies that did not have a manufacturing process in their facilities were discarded. A survey was carried out to collect the data, conducted through personal interviews with managers of companies. The questionnaire designed was subject to the analysis of various experts, both academics and specialists. As a result, a pretest was then formed and conducted upon five manufacturers. The questionnaire developed contains components that collect information from the company and a number of questions related to the main variables of the model, the questions grouped by topic. Fieldwork was conducted during the months of 
September to December 2013, the questionnaire was applied to the manager of the company, 180 interviews were conducted and 150 questionnaires answered correctly. The descriptive statistics of the sample can be seen in Table 1. According to Podsakoff, MacKenzie, Lee and Podsakoff (2003), if the interest of the research is to relate behavior variables of the company, the researcher can obtain measurements of the behavior of the company from key informants as managers or executives. On the other hand, studies using information on the behavior of the organization should take into account the different methods of bias that may influence on the response process (Meade, Watson \& Kroustalis, 2007). In this paper we control this influence on the research design (Podsakoff et al., 2003).

\begin{tabular}{|c|c|}
\hline Number of manufacturing SMEs & 150 \\
\hline Manager & Percentage \\
\hline University degree & 22 \\
\hline No university degree & 78 \\
\hline \multicolumn{2}{|l|}{ SMEs Manufacturers (Activity Sector) } \\
\hline Food industry & 18 \\
\hline Metal mechanics & 34 \\
\hline Electrical- electronic & 22 \\
\hline Others & 26 \\
\hline \multicolumn{2}{|l|}{ Patents } \\
\hline Companies with patents & 61 \\
\hline Companies without patents & 39 \\
\hline \multicolumn{2}{|l|}{ Export Activity } \\
\hline Export firms & 40 \\
\hline No export firms & 60 \\
\hline \multicolumn{2}{|l|}{ Size } \\
\hline Micro enterprises ( $<10$ employees) & 53 \\
\hline Small businesses ( $<50$ employees) & 42 \\
\hline Medium enterprises ( $<250$ employees) & 5 \\
\hline \multicolumn{2}{|l|}{ Certification } \\
\hline Quality certificate ISO 9001 & 47 \\
\hline Without quality certificate & 53 \\
\hline Environmental certificate ISO 14001 & 21 \\
\hline Without environmental certificate ISO 14001 & 79 \\
\hline \multicolumn{2}{|l|}{ Age } \\
\hline Under 6 years & 8 \\
\hline Less than 20 years & 42 \\
\hline More than 20 years & 50 \\
\hline \multicolumn{2}{|l|}{ Annual Sales } \\
\hline Less than $100.000 €$ & 4 \\
\hline Between 100.000 and 1 million $€$ & 54 \\
\hline Between 1 million and 10 million€ & 42 \\
\hline
\end{tabular}

Table 1. Characteristics of Responding Firms 


\subsection{Statistical Analysis}

Structural equation modeling via PLS (Partial Least Squares) is the method for data analysis and for assessing the relationships between constructs, considering the characteristics of model (predictive) and sample (fewer than 250 subjects) (Reinartz, Haenlein \& Hesenler, 2009). The adequacy of this technique to our research is for various reasons:

- PLS is particularly useful when carrying out a mediation analysis and the sample size is small.

- PLS is primarily intended for causal- predictive analysis, where the problems explored are complex and prior theoretical Knowledge is scarce (Wold, 1985).

- PLS is robust for small to moderate sample sizes (Cassel, Hackl \& Westlund, 1999).

- PLS is a regression-based structural equation modeling (SEM) technique that does not make assumptions about data distributions, employing a principal component-based estimation approach (Chin, 1998b).

- PLS avoids many of the restrictive assumptions underlying maximum likelihood techniques and ensures an accurate result, preventing improper solutions and factor indeterminacy (Podsakoff \& Organ, 1986).

- PLS drives both reflective and formative constructs and handles both very small and very large samples more easily than SEM does (Hair, Ringle \& Sarstedt, 2013).

- PLS is an appropriate alternative to Structural Equation Modeling develop in the Organization and Management (Chin, 2008; Cepeda \& Roldan, 2008)

The software used was SmartPLS 2.0 M3, developed by Ringle, Wende and Will (2005). The model estimation is completed in two steps (Chin, Marcolin \& Newsted, 2003). First the measurement model is analyzed, where the relationship between the indicators and the latent construct is checked. Secondly, the structural model is analyzed, where the relationships between constructs through the path coefficients and the level of significance are tested. The tests to be performed for the measurement model depend on the nature of the direction of causality between the indicator and the construct; this being a reflective construct if the direction of causation runs from the construct to the indicator, and being the formative construct if the direction of causality runs from the indicator to the construct. Formative specification is appropriate when indicators directly help create the construct, while the reflective specification assumes that indicators reveal latent characteristics in the construct (Chin, 1998a). Reflective indicators are defined by the conceptual dimension that represents the construct; there should hence be a high correlation between them as indicators attempt to measure the same concept. A construct with formative indicators implies that indicators need 
not be highly correlated with each other, but each indicator can occur independently (Podsakoff, Shen \& Podsakoff, 2006).

Therefore, treatment for traditional measures of validity and reliability are not applicable for the formative indicators, although we must assess possible problems of collinearity (Chin, 1998b), as this would indicate that there is a conceptual redundancy between the indicators' construct (Cenfetelli \& Bassellier, 2009), that is, some of the indicators would be measuring the same facet of the latent construct.

\section{Results}

\subsection{Measurement Model}

Measurement variables: The proposed model contains the following constructs: sustainability, innovative orientation, corporate image and export performance. A previous review of the literature was needed to build the indicators used to measure the variables studied. All indicators have been obtained by consulting experts and through the literature review. All variables used in this study were measured by constructs with scales of measurement, which represent the manager's perception regarding the model variables. The indicators were established based on a Likert scale ( 1 "emphasis very low" and 5 "emphasis very high"), except CI5, IO7, IO6, S5, which are dichotomous and EP1, EP2, EP3, EP4 which are ordinals.

Control variables in the model: the age (number of years of the company in the market since its founding) and the size (number of employees)of the company belongs to have been included as control variables in order to neutralize their effects over the dependent variable, thus obtaining a parsimonious model (Mesquita \& Lazzarini, 2008).

\subsubsection{For ReflectiveConstruct}

PLS is performed by analyzing reliability through internal consistency, and convergent and discriminant validity (Fornell \& Larcker, 1981; Tenenhaus, Vinzi, Chatelin \& Lauro, 2005). This involves analyzing whether the observed variables (theoretical concepts) are correctly measured through their indicators. In our model, the only reflective construct is export performance that is measured by means of four indicators (EP1, EP2, EP3 y EP4). The Table 2 shows the individual reliability, internal consistency, convergent validity, and discriminant validity of export performance. The first criterion is established through analysis of the factor loadings (Chin, 1998b). The factor loadings obtained on the export performance were higher than the recommended value of 0.7 , showing a good individual reliability. Composite reliability, Cronbach $a$ and communality exceed the threshold value (Cronbach a 0.7, 
communality $>0.7$, and composite reliability $>0,7$ ) for internal consistency (Nunnally, 1978). The convergent validity of the reflective construct was analyzed through average variance extracted (AVE). Convergent validity was considered adequate when the AVE indicator reaches values higher than 0.5 (Fornell \& Larcker, 1981; Chin, 1998b). In this construct, we have achieved a value of 0.7495 for the average variance extracted in export performance, so the mentioned construct has convergent validity. In turn, discriminant validity is good because the square root of the average variance extracted ( $A V E$ ) is higher than the correlation between the construct and the other latent variables, indicating that the construct shares a higher variance with their own indicators than with the other indicators of the model. Therefore, these results confirm that the reflective variable in the model (export performance) is reliable and consistent.

\begin{tabular}{|c|c|c|c|c|}
\hline Variable & AVE & CR & $\begin{array}{c}\text { Alpha } \\
\text { Cronbachs }\end{array}$ & $\begin{array}{c}\text { Communali } \\
\text { ty }\end{array}$ \\
\hline Export Performance (E.P) & 0.7495 & 0.9225 & 0.8867 & 0.7495 \\
\hline Indicators & Factor Loading & & & \\
\hline $\begin{array}{l}\text { EP1: Measures the difference } \\
\text { between the percentage of total sales } \\
\text { exported in } 2013 \text { and } 2005 \text {. }\end{array}$ & 0.952 & & & \\
\hline $\begin{array}{l}\text { EP2: Percentage of total sales } \\
\text { directed abroad in } 2013\end{array}$ & 0.815 & & & \\
\hline EP3: Number of years exporting. & 0.796 & & & \\
\hline EP4: Number export regions. & 0.891 & & & \\
\hline Discriminant Validity & Export Performance (E.P) & & & \\
\hline Export Performance (E.P) & $(\mathrm{AVE})^{1 / 2}=0.866$ & & & \\
\hline Corporate Image (C.I.) & 0.4447 & & & \\
\hline Innovative Orientation (I.O) & 0.2891 & & & \\
\hline Sustainability (S) & 0.1956 & & & \\
\hline
\end{tabular}

Table 2. Measuring Model for Reflective Construct

\subsubsection{For FormativeConstructs}

In the measurement model for constructs with formative indicators, content validity of the indicators and their conceptual dimension are very important so the weights obtained from the indicators are shown in Table 3. Although loadings were positive for all indicators, we had to remove indicators IC4 and OI4, because the weight was almost zero. Secondly, the variance inflation factor (VIF) was used to ensure no collinearity occurred. For some authors, it is recommended that its value must be less than 3.3 to show absence of collinearity (Petter, Straub \& Rai, 2007). However, other studies consider values below 5 VIF (Hair et al., 2013), or even less than 10 acceptable (Diamantopoulos, Reynolds \& Simintiras, 2006). In our case, all the values obtained were less than 1.73 which, being less than 3.3 , ensures that there are no 
problems of collinearity. The Table 3 shows the result of measurement model for formative constructs.

\begin{tabular}{|c|c|c|c|}
\hline CONSTRUCT/ Indicators (conceptual dimension) & Weights & Loading & VIF \\
\hline \multicolumn{4}{|l|}{ Sustainability (S) } \\
\hline S1: The company's commitment to the environment & 0.235 & 0.5410 & 1.563 \\
\hline S2: Usage of a proper waste management system. & 0.409 & 0.6812 & 1.725 \\
\hline S3: Recycling of leftover materials. & 0.307 & 0.4898 & 1.221 \\
\hline S4: Manufacturing of products from recycled or organic materials. & -0.182 & 0.0293 & 1.116 \\
\hline S5: ISO certification for environmental management. & 0.633 & 0.7085 & 1.014 \\
\hline \multicolumn{4}{|l|}{ Innovative Orientation (I.0) } \\
\hline OI1: Developing new products and technology. & -0.133 & 0.4095 & 1.524 \\
\hline $\begin{array}{l}\text { OI2: Company's care for improving the organizational structure, administrative } \\
\text { processes and human resources. }\end{array}$ & 0.449 & 0.4071 & 1.464 \\
\hline OI3: Improvement in production process. & 0.658 & 0.6063 & 1.180 \\
\hline OI4: Sticking with its sponsors when someone suggests a new idea. & 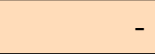 & - & - \\
\hline OI5: Developing R \& D activities & 0.280 & 0.8083 & 1.107 \\
\hline OI6: The Company's patents & 0.293 & 0.4630 & 1.107 \\
\hline \multicolumn{4}{|l|}{ Corporate Image (C.I.) } \\
\hline $\begin{array}{l}\text { IC1: Transmission of the mission, values and corporate objectives to employees } \\
\text { and customers. }\end{array}$ & 0.454 & 0.6609 & 1.137 \\
\hline IC2: Concern for the company's corporate image (web, setting, colors, logo). & 0.254 & 05581 & 1.564 \\
\hline IC3: Manufactured products differ from the competition due to corporate image. & 0.284 & 0.5705 & 1.469 \\
\hline IC4: Considering advertising expenditures adequate for promoting its products & - & - & - \\
\hline IC5: ISO quality certificate for use by the company's image. & 0.572 & 0.6918 & 1.060 \\
\hline
\end{tabular}

Table 3. Measurement Model for Formative Constructs

\subsection{Structural Model}

Structural analysis assesses the power of the relations established between the different variables in the model. The goodness of fit in the model is revealed through the T-Student value, the level of significance of the structural paths " $\beta$ " or Path coefficients, and the coefficient of determination (R2) for "export performance" (dependent variable). In our model with mediated effects, the hypothesis ( $\mathrm{H} 3$ and $\mathrm{H} 4)$, are accept when Path coefficients are significant according to a Student's t distribution with two-tailed due to the mediating effect. In our model without mediated the hypothesis ( $\mathrm{H} 1$ and $\mathrm{H} 2)$, are accept when Path coefficients are significant according to a Student's t distribution with one-tailed due to direct relations with a positive sign. To estimate the coefficients Path, a Bootstrap re-sampling procedure with 5000 subsamples was carried out.

In order to test whether corporate image has a complete or partial mediation effect, Baron and Kenny (1986) and Shaver (2005) suggest that firstly the estimation of the model without the 
mediating variable (testing the direct relationships between sustainability and innovativeness with export performance), and secondly the estimation of the model with the mediating variable. The results of structural analysis are shown in Figure 2.

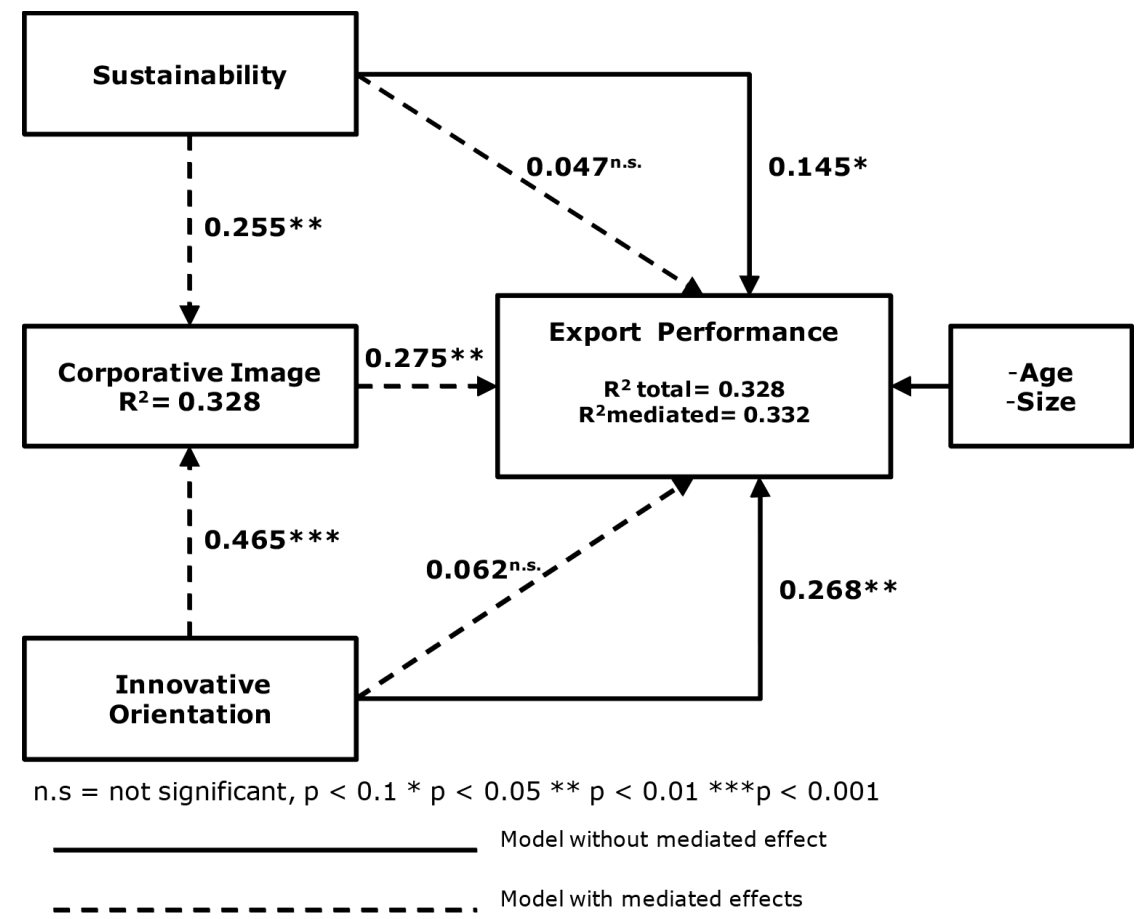

Note: Model with mediated effect based on a Student's two tailed distribution; model without mediated effect based on a Student's one-tailed distribution. Bootstrap for $n=5000$ subsamples.

Figure 2. Structural Model Results

As seen in the Figure 2, the results analysis shows that there is a positive and significant influence between sustainability on the export performance $(\beta=0.145$, bootstrap $t=2.113)$ also there is a positive and significant influence between innovative orientation on the export performance $(\beta=0.268$ bootstrap, $t=3.288)$. The first and second hypotheses are therefore supported.

If the mediating variable is introduced into the model (corporate image) and the of path coefficient of the direct relations reduced to a value close to zero at the same time increases the value of the coefficient of determination R2 for variable explained (export performance), according to Baron and Kenny (1986) and Shaver (2005), corporate image variable acts as a mediating variable and the mediator effect is complete.

According to the results obtained, sustainability has a positive influence on corporate image $(\beta=0.255$, bootstrap $t=3.181)$ and innovative orientation very important positive influences on corporate image $(\beta=0.465$, bootstrap $t=5.487)$, but instead corporate image has a positive and 
significant effect on export performance $(\beta=0.275$, bootstrap $t=3.138)$. In addition, according to Baron and Kenny (1986) and Shaver (2005), the mediator effect is complete if the relationship between sustainable and innovative orientation on the export performance is reduced to a value close to zero $(\beta=0.047$ and $\beta=0.062)$ when the model incorporates the mediating variable; in our case, the corporate image generated by the company (see Figure 2 ). So the mediator effect of corporate image on "sustainability - export performance" and "innovative orientation - export performance" is complete. These results support third and fourth hypotheses. On one hand, the influence of innovation orientation on the export performance is mediated through the corporate image, which acts as a mediating variable. On the other hand, sustainability on export performance is mediated through the corporate image, which acts as a mediating variable. The foregoing results show that all hypotheses are supported. We also found that sustainability and innovative orientation contributes to an improved corporate image this in turn improves export performance. Finally, we will examine the explained variance of the dependent variables. With respect to the control variables, the age of the firm was not significant but the size of the company was significant in both models (according to the literature a greater number of employees increased resources).

The goodness of fit in the model was tested through the R2 (coefficient of determination) value for each explained variable; in our case the R2 was valued in corporate image and export performance. The model with mediated effects explains 33.2 percent of the variance of the export performance, and sustainability and innovative orientation are able to explain 32.8 percent of the variance of the corporate image. The model without mediated effects explains 32.8 percent of the variance of the export performance. Therefore, the value of R2 with regard to export performance increases by introducing the mediating variable, from a value of 32.8 percent (without mediated effect) to 33.2 percent (with mediated effect), which according to the literature confirms that our model presents a complete mediation. Furthermore, Falk and Miller (1992) note that if the R2 is greater than 0.1 , then the model has predictive relevance. This implies that the two models analyzed have predictive relevance. Finally, the results obtained show that the management of corporate image as an intangible resource has great potential and importance on the growth of SMEs, particularly in exports.

\section{Conclusions}

In recent years, corporate image has been identified as an important strategic intangible since its design and management offers potential benefits to the company in multiple sectors. This research comprises a model that demonstrates an interesting explanation of how corporate image plays an important role in the competitive success of a company in foreign markets. When a manufacturing company competes in international trade, it is able to create a competitive advantage for itself by producing the same product with fewer resources or by 
creating innovative products that the market is willing to pay a premium for. Sustainability and innovative orientation of companies is very important due to changes that originate in consumer values' regarding environmental care, greener products, eco or recyclable or due to technological use of the product. Managers of SMEs who promote innovativeness are also key, as the competitive advantage of a company roots from continuous improvement and changes experimented with in the company. Companies gain advantage over their domestic and international competitors when they manifest a new basis for competition and innovation in strategic terms. From a global point of view this includes new technologies, new organizational methods or ways of doing things. Intangible resources depend largely on organizational culture, due to the ways in which the organization carries out its mission. For this reason, it was very interesting to study the impact of corporative image on export performance in manufacturing SMEs. We have provided new evidence for the creation of corporate image not only as a result of tangible items, but as a result of the actions and behavior of the company. We were hence able to show that there is a high level of complexity in the management of intangibles since the intangibles influence each other, such as the influence of sustainability and innovative orientation on corporate image as demonstrated in this research. The framework proposed in this paper is to encourage managers to implement strategies and policies to take into further account the image generated by their organization. To do this, the research model was designed according to the Theory on Resources and Capabilities, and the Theory of Dynamic Capabilities. Through this study we propose how business value can be improved through corporate image, which is overseen by the company's management team, when the company decides to introduce its products in foreign markets. Based on the idea that corporate image is a strategic resource to create a competitive advantage in international markets, and given the small amount of research which addresses this issue, we have tried to clarify the true role of the corporative image generated by the company in relation to sustainability and innovative orientation on export performance, detecting that the image acts as a filter for both sustainable efforts and innovators in products or processes. However, to clarify this complex phenomenon, we have established a useful empirical model to understand how proper management of the company image (from an internal perspective) has a positive impact on export performance. Therefore, managers should focus on proper design and management of the company image, in order to compete and grow in the international area.

A possible limitation of this study is that the survey was restricted to firms in Seville (Spain), which could raise questions regarding the extent to which the findings can be generalised. Testing the external validity of the findings would necessitate replication of this study in other countries. The study also employed a cross-sectional research design, which could be criticized for failing to capture the dynamic aspects of the constructs incorporated in the model. Thus, future work should consider adopting a longitudinal design that would provide an insight into these relationships over time. It would also have been interesting to undertake the same study by sectors, due to the differences found in researchers dealing with export success being due 
to different manufacturing sectors (Robertson \& Chetty, 2000). Finally, it can be said that on the basis of this study, future research lines related with this subject are opened, creating the possibility of widening the analysis with different intangible aspects that have not been included in this research. In addition, future studies should continue to investigate the mediating role of corporate image generated in organization compared with other business variables.

\section{References}

Aaby, N.E., \& Slater, F.S. (1989). Managerial Influences on Export Performance Review of the Empirical Literature 1978-88. International Marketing Review, 6(4), 7-26.

Acedo, F.J., \& Galán, J.L. (2011). Export stimuli revisited: The influence of the characteristics of managerial decision makers on international behavior. International Small Business Journal, 29, 648-670. http://dx.doi.org/10.1177/0266242610375771

Adair, J. (1992). The managerial challenge of innovation. Bogotá: Legis.

Balmer, J.M.T. (1995). Corporate branding and connoisseurship. Journal of General Management, 21(1), 24-46.

Barney, J.B. (1991). Firm Resources and Sustained Competitive Advantage. Journal of Management, 17(1), 99-120. http://dx.doi.org/10.1177/014920639101700108

Baron, R.M., \& Kenny, D.A. (1986). The moderator-mediator variable distinction in social psychological research: conceptual, strategic, and statistical considerations. Journal of Personality and Social Psychology, 51(6), 1173-1182. http://dx.doi.org/10.1037/0022-3514.51.6.1173

Bernstein, D. (1986). Company Image and Reality. A Critique of Corporate Communications. UK: Eastbourne.

Bilkey, W.J. (1978). An Attempted Integration of the Literature on the Export Behavior of Firms. Journal of International Business Studies, 9, 33-46. http://dx.doi.org/10.1057/palgrave.jibs.8490649

Bromley, D.B. (2000). Psychological Aspects of Corporate Identity, Image and Reputation. Corporate Reputation Review, 3(2), 240-252. http://dx.doi.org/10.1057/palgrave.crr.1540117

Capriotti, P. (1999). Strategic planning of corporate image. Barcelona: Ariel.

Cassel, C., Hackl, P., \& Westlund, A.H. (1999). Robustness of Partial Least Squares method for estimating latent variable quality structures. Journal of Applied Statistics, 26(4), 435-446. http://dx.doi.org/10.1080/02664769922322 
Cenfetelli, R.T., \& Bassellier, G. (2009). Interpretation of Formative Measurement in Information Systems Research. MIS Quarterly, 33(4), 689-708.

Cepeda, G., \& Roldán, J. (2008). Applying in practice the PLS tecnique in business administration. Universidad de Sevilla, España.

Chetty, S.K., \&. Hamilton, R.T. (1993). Firm-Level Determinants of Export Performance: A Metaanalysis. International Marketing Review, 10(3), 26-34. http://dx.doi.org/10.1108/02651339310040643

Chien, M.K., \& Shih, L.H. (2007). An empirical study of the implementation of green supply chain management practices in the electrical and electronic industry and their relation to organizational performance. International Journal of Environment Science and Technology, $4(3), 383-394$.

Chin, W.W. (1998a). Issues and Opinion on Structural Equation Modeling. MIS Quarterly, 22(1), 7-16.

Chin, W.W. (1998b). The partial least squares approach to structural equation modeling. In Marcoulides, G.A. (Ed.). Modern Methods for Business Research. Mahwah, NJ: Lawrence Erlbaum Associates. 295-336.

Chin, W.W. (2008). Conference: Exploring a broader view technology acceptance: Locking forward toward an understanding of the nature of definition of IT acceptance. Dpto. de Administración de Empresas y Marketing, de la Universidad de Sevilla, mayo, 2008.

Chin, W.W., Marcolin, B.L., \& Newsted, P.R. (2003). A Partial Least Squares Latent Variable Modeling Approach for Measuring Interaction Effects: Results from a Monte Carlo Simulation Study and an Electronic-mail Emotion/Adoption Study. Information Systems Research, 14(2), 189-217. http://dx.doi.org/10.1287/isre.14.2.189.16018

Cordano, M., \& Frieze, I.H. (2000). Pollution reduction preferences of U.S. environmental managers: Applying ajzen's theory of planned behavior. Academy of Management Journal, 43, 627-641. http://dx.doi.org/10.2307/1556358

Diamantopoulos, A., Reynolds, N.L., \& Simintiras, A.C. (2006). The impact of Response Styles on the Stability of Cross-national Comparisons. Journal of Business Research, 59(8), 925-935. http://dx.doi.org/10.1016/j.jbusres.2006.03.001

Dowling, G. (1994). Corporate reputations: strategies for developing the corporate brand. London: Kogan Page.

Drucker, P. (1986). Innovation and entrepreneurship: principles and practices. Buenos Aires: Editorial Suramericana. 
Drucker, P. (2000). Management in the future society. Bogotá: Norma.

Falk, R.F., \& Miller, N.B. (1992). A Primer for Soft Modeling. Akron: University of Akron Press.

Flannery, B.L., \& May, D.R. (2000). Environmental ethical decision making in the U.S. metal-finishing industry. Academy of Management Journal, 43, 642-662. http://dx.doi.org/10.2307/1556359

Fonseca, L. (2012). Influence of Social Responsibility of organisations on theirs Sustainable Success, PhD Thesis, ISCTE-IUL, Lisbon, Portugal.

Fonseca, L.M. (2015). ISO 14001:2015: An improved tool for sustainability. Journal of Industrial Engineering and Management, 8(1), 37-50.

Fonseca, L.M., \& Lima, V.M. (2015). Sustainability, Innovation, and Competitiveness. Journal of Industrial Engineering and Management, 8(4), 1288-1302. http://dx.doi.org/10.3926/jiem.1525

Fornell, C., \& Larcker, D. (1981). Evaluating structural equation models with unobservable variables and measurement error. Journal of Marketing Research, 18, 39-50. http://dx.doi.org/10.2307/3151312

Freel, M.S., \& Harrison, R.T. (2006). Innovation and cooperation in the small firm sector: Evidence from "Northern Britain". Regional Studies, 40(4), 289-305. http://dx.doi.org/10.1080/00343400600725095

Freeman, C. (1982). The Economics of Industrial Innovation, MIT Press. E.B. Roberts. "What we've learned: Managing invention and innovation". Research Technology Management, 31(1), 11-29.

Gebauer, A., Woon-Nam, C., \& Parsche, R. (2005). Regional technology policy and factors shaping local innovation networks in small German cities. European Planning Studies, 13(5), 661-683. http://dx.doi.org/10.1080/09654310500139301

Gemunden, H.G. (1991). Success Factors of Export Marketing. Londres: Paliwoda.

Gioia, D., Schultz, M., \& Corley, K. (2000). Organizational Identity, Image, and Adaptative Instability. The Academy of Management Review, 25(1), 63-81.

Hair, J.F., Ringle, C.M., \& Sarstedt, M. (2013). Editorial Partial Least Squares Structural Equation Modeling: Rigorous Applications, Better Results and Higher Acceptance. Long Range Planning, 46, 1-12. http://dx.doi.org/10.1016/j.Irp.2013.01.001

Hamel, G., \& Prahalad, C.K. (1990). The Core Competence of the Corporation. Harvard Business Review, 68(3), 79-91. 
Hansen, G., \& Wernerfelt, B. (1989). Determinants of Firm Performance: The Relative Importance of Economic and Organizational Factors. Strategic Management Journal, 10(5), 399-411. http://dx.doi.org/10.1002/smj.4250100502

Kanter, R.M. (1987). The Art of Innovation. Chicago: Tape Lecture Nighthin Gale Corporation.

Kaufmann, A., \& Tödtling, F. (2002). How effective is innovation support for SMEs? An analysis of the region of Upper Austria. Technovation, 22(3), 147-159. http://dx.doi.org/10.1016/S01664972(00)00081-X

Leonidou, L.C., Katsikeas, C.S., \& Piercy, N.F. (1998). Identifying Managerial Influences on Exporting: Past Research and Future Directions. Journal of International Marketing, 6(2), 74-102.

Leonidou, L.C., Katsikeas, C.S., \& Samiee, S. (2002). Marketing strategy determinants of export performance: a meta-analysis. Journal of Business Research, 55(1), 51-67. http://dx.doi.org/10.1016/S0148-2963(00)00133-8

Lewis, G.J., \& Harvey, B. (2001). Perceived environmental uncertainty: The extension of miller's scale to the natural environment. Journal of Management Studies, 38, 201-233. http://dx.doi.org/10.1111/1467-6486.00234

Madsen, T.K. (1987). Successful Export Marketing Management: Some Empirical Evidence. International Marketing Review, 6(4), 41-57.

Marcus, A., \& Fremeth, A. (2009). Green management matters regardless. The Academy of Management Perspectives, 23, 17-26. http://dx.doi.org/10.5465/AMP.2009.43479261

Martinez, F. (1991). Planificación estratégica. Mexico DF: Creativa Editorial PAC.

Meade, A.W., Watson, A.M., \& Kroustalis, C.M. (2007). Assessing Common Methods Bias in Organizational Research. Paper presented at the 22nd Annual Meeting of the Society for Industrial and Organizational Psychology. New York.

Mesquita, L.F., \& Lazzarini, S.G. (2008) Horizontal and vertical relationships in developing economies: implications for SMEs' access to global markets. Academy of Management Journal, 51(2), 359-380. http://dx.doi.org/10.5465/AMJ.2008.31767280

Miesenbock, K.J. (1988). Small Business and Exporting: A Literature Review. International Small Business Journal, 6, 42-61. http://dx.doi.org/10.1177/026624268800600204

Navarro-García, A., Schmidt, A.C.M., \& Rey-Moreno, M. (2015). Antecedents and consequences of export entrepreneurship. Journal of Business Research, 68(7), 1532-1538. http://dx.doi.org/10.1016/j.jbusres.2015.01.047 
Nunally, J.C. (1978). Psychometric Theory. New York: McGraw-Hill.

Penrose, E. (1959). The theory of the growth of the firm. Oxford: Basil Blackwell.

Peters, T., \& Austin, N. (1989). Passion for Excellence, different characteristics of the leading companies. Barcelona: Ed. Folio.

Petter, S., Straub, D., \& Rai, A. (2007). Specifying Formative Constructs in Information Systems Research. MIS Quarterly, 31 (4), 623-656.

Podsakoff, N.P., Shen, W., \& Podsakoff, P.M. (2006). The role of formative measurement models in strategic management research: Review, critique, and implications for future research. Research Methods in Strategy and Management, 3, 201-256. http://dx.doi.org/10.1016/s14798387(06)03008-6

Podsakoff, P.M., \& Organ, D.W. (1986). Self-reports in organizational research: Problems and prospects. Journal of Management, 12, 531-544. http://dx.doi.org/10.1177/014920638601200408

Podsakoff, P., Mackenzie, S., Lee, J., \& Podsakoff, N. (2003). Common method biases in behavioral research: A critical review of the literature and recommended remedies. Journal of Applied Psychology, 88, 879-903. http://dx.doi.org/10.1037/0021-9010.88.5.879

Porter, M.E., \& Van Der Linde, C. (1995). Toward a new conception of the environment competitiveness relationship. The Journal of Economic Perspectives, 9, 97-118. http://dx.doi.org/10.1257/jep.9.4.97

Porter, M.E. (1991). The Competitive Advantage of Nations. New York: Free Press.

Ramus, C.A., \& Steger, U. (2000). The roles of supervisory support behaviors and environmental policy in employee (ecoinitiatives) at leading-edge European companies. Academy of Management Journal, 43, 605-626. http://dx.doi.org/10.2307/1556357

Reinartz, W., Haenlein, M., \& Henseler, J. (2009). An empirical comparison of the efficacy of covariance-based and variance-based SEM. International Journal of Research in Marketing, 26(4), 332-344. http://dx.doi.org/10.1016/j.ijresmar.2009.08.001

Rhee, J., Park, T., \& Lee, D.H. (2010). Drivers of innovativeness and performance for innovative SMEs in South Korea: Mediation of learning orientation. Technovation, 30, 65-75. http://dx.doi.org/10.1016/j.technovation.2009.04.008

Ringle, C., Wende, S., \& Will, A. (2005). Smart PLS 2.0 (M3). Hamburg. http://www.smartpls.de 
Robertson, C., \& Chetty, S.K. (2000). A contingency-based approach to understanding export performance. International Business Review, 9(2), 211-235. http://dx.doi.org/10.1016/S09695931(99)00037-2

Rumelt, R. (1991). How Much Does Industry Matter? Strategic Management Journal, 12, 167-185. http://dx.doi.org/10.1002/smj.4250120302

Schmitt, B.H., Simonson, A., \& Marcus, J. (1995). Managing Corporate Image and Identity. Long Range Planning, 28(5), 82-92. http://dx.doi.org/10.1016/0024-6301(95)00040-P

Seuring, S. (2004). Industrial ecology, life cycles, supply chains: Differences and interrelations. Business Strategy and the Environment, 13(5), 306-319. http://dx.doi.org/10.1002/bse.418

Sharma, S. (2000). Managerial interpretations and organizational context as predictors of corporate choice of environmental strategy. Academy of Management Journal, 43, 681-697. http://dx.doi.org/10.2307/1556361

Shaver, J.M. (2005). Testing for mediating variables in management research: concerns, implications, and alternative strategies. Journal of Management, 31, 330-353. http://dx.doi.org/10.1177/0149206304272149

Shoam, A. (1998). Export performance: A conceptualization and empirical assessment. Journal of International Marketing, 6(3), 59-81.

Shrivastava, P. (1995). The role of corporations in achieving ecological sustainability. Academy of Management Review, 20, 936-960.

Simoes, C., Dibb, S., \& Fisk, R.P. (2005). Managing corporate identity: An internal perspective. Journal of the Academy of Marketing Science, 33(2), 153-168. http://dx.doi.org/10.1177/0092070304268920

Sousa, C., Lengler, J., \& Martínez-López, F. (2014). Testing for Linear and Quadratic Effects between Price Adaptation and Export Performance: The Impact of Values and Perceptions. Journal of Small Business Management, 52(3), 501-520. http://dx.doi.org/10.1111/jsbm.12046

Tarí, J.J., Molina-Azorín, J.F., \& Heras, I. (2012). Benefits of the ISO 9001 and ISO 14001 standards: A literature review. Journal of Industrial Engineering and Management, 5(2), 297-322. http://dx.doi.org/10.3926/jiem.488

Teece, D.J. (2007). Explicating Dynamic Capabilities. The Nature and Microfoundations of (Sustainable) Enterprise Performance. Strategic Management Journal, 28(13), 1319-1350. http://dx.doi.org/10.1002/smj.640 
Teece, D.J., \& Pisano, G. (1994). The Dynamic Capabilities of Firms: An Introduction. Industrial and Corporate Change, 3(3), 537-556. http://dx.doi.org/10.1093/icc/3.3.537-a

Teece, D.J., Pisano, G., \& Shuen, A. (1997). Dynamic Capabilities and Strategic Management. Strategic Management Journal, 18(7), 509-533. http://dx.doi.org/10.1002/(SICI)10970266(199708)18:7<509: :AID-SMJ882>3.0.CO;2-Z

Tenenhaus, M., Vinzi, V.E., Chatelin, Y., \& Lauro, C. (2005). PLS Path Modeling. Computational Statistics \& Data Analysis, 48(1), 159-205. http://dx.doi.org/10.1016/j.csda.2004.03.005

Tran, M.A., Nguyen, B., Melewar, T.C., \& Bodoh, J. (2015). Exploring the corporate image formation process. Qualitative Market Research: An International Journal, 18(1), 86-114. http://dx.doi.org/10.1108/QMR-05-2014-0046

Valdés, L. (2002). Corporate re-evolution of XXI century. Bogotá: Editorial Norma.

Van Rekom, J. (1993). Corporate Identity - Its Measurement and Use in Corporate Communications. Proceedings of the European Marketing Association Conference, 1497-1514.

Villafañe, J. (1993). Positive image. Strategic management of corporate image. Madrid: Pirámide.

Villafañe, J. (1999). La gestión profesional de la imagen corporativa. Madrid: Pirámide.

Villena-Manzanares, F., \& Souto-Pérez, J.E. (2015). The impact of strategic intangible on the export performance of the manufacturing SMEs (El impacto de los intangibles estratégicos en el desempeño exportador de la PYME manufacturera). Intangible Capital, 11(1), 13-40. http://dx.doi.org/10.3926/ic.567

Welch, L.S., \& Loustarinen, R. (1988). Internationalization: Evolution of a concept. Journal of General Management, 14, 34-55.

Wernerfelt, B., \& Montgomery, C.A. (1988). Tobin's q and the Importance of Focus in Firm Performance. American Economic Review, 78, 246-250.

Wold, H. (1985). Systems analysis by Partial Least Squares. In Nijkamp, P., Leitner, H., \& Wrigley, N. (Eds.). Measuring the Unmeasurable. Dordrecht: Martinus Nijhoff Publishers. 221-251. http://dx.doi.org/10.1007/978-94-009-5079-5_11

World Commission on Environment and Development (1987). Our common future. New York, NY: Oxford University Press.

Zajac, E.J., Kraats, M.S., \& Bresser, R.F.K. (2000). Modeling the Dynamics of Strategic Fit: A Normative Approach to Strategic Change. Strategic Management Journal, 21(4), 429-453. http://dx.doi.org/10.1002/(SICI)1097-0266(200004)21:4<429: :AID-SMJ81>3.0.CO;2-\# 
Zinkhan, G., Jaishankar, G., Anupam, J., \& Linda, H. (2001). Corporate Image: A Conceptual Framework for Strategic Planning, Conference. Washington, D.C.: Marshall.

Zou, S., \& Stan, S. (1998). The determinants of export performance: A review of the empirical literature between 1987 and 1997. International Marketing Review, 15(5), 333-357. http://dx.doi.org/10.1108/02651339810236290

Zou, S., Taylor, C., \& Osland, G., (1998). The experf Scale: A Cross-National Generalized Export Performance Measure. Journal of International Marketing, 6(3), 37-58.

Journal of Industrial Engineering and Management, 2016 (www.jiem.org)

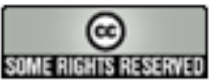

Article's contents are provided on an Attribution-Non Commercial 3.0 Creative commons license. Readers are allowed to copy, distribute and communicate article's contents, provided the author's and Journal of Industrial Engineering and Management's names are included. It must not be used for commercial purposes. To see the complete license contents, please visit http://creativecommons.org/licenses/by-nc/3.0/. 